able various muscle samples. The encouragement of Prof. D. Keilin throughout these investigations is gratefully acknowledged.

The work described in this communication was carried out as part of the joint programme of the Food Investigation Organization, Department of Scientific and Industrial Research, and of the Scientific Adviser's Division, Ministry of Food.

Low Temperature Station

R. A. LAWRIE

for Research in Biochemistry and Biophysics, University of Cambridge, and

Department of Scientific and Industrial Research. Jan. 7 .

${ }^{1}$ Lawrie, R. A., J. Agric. Sci., 40, 356 (1950).

2 Keilin, D., and Hartree, E. F., Biochem. J., 41, 503 (1947).

${ }^{3}$ Slater, E. C., Biochem. J., 44, 305 (1949).

- Slater, I. C., Biochem. J., 45, 1 (1949).

5 Tsou, C. L., Biochem. J., 48, Proc. lii (1951).

'Allen, R. J. I., Biochem. J., 34, 858 (1940).

- Marsh, B. B., Biochim. Biophys. Acta (in the press)

\section{Paper Electrophoresis of Serum Proteins}

THE separation of the albumin, $\alpha_{1^{-}}, \alpha_{2^{-}}, \beta-$ and $\gamma$-globulin fractions of serum protein can be accomplished by electrophoresis on filter paper ${ }^{1-3}$. The protein fractions are delineated as bands by drying the paper, and then staining with bromphenol blue. Cremer and Tiselius ${ }^{2}$ estimated the fractions by elution of $5-\mathrm{mm}$. strips of the filter paper, the concentration of the dye from each strip being determined colorimetrically. A curve is thus obtained, similar to that from the classical 'Tiselius electrophoresis.

The separation by paper electrophoresis is elegant, and the apparatus simple, but the elution of dye from thirty to forty pieces of filter paper is both tedious and time-consuming, besides having theoretical objections. To simplify the procedure, and make it more adaptable for routine clinical laboratory analysis, we cut out, after staining, whole bands representing protein fractions and estimate the protein by Kjeldahl analysis of the filter paper. If an accurately measured amount of serum protein is used initially, the fractions are thus directly estimated in terms of protein nitrogen. This method gives duplicate results which appear to be as accurate as those obtained by the much longer procedure of elution. A comparison of the results of the analysis of a serum (converted into percentages of total protein) both by this method and that of the classical Tiselius separation is given herewith.

\begin{tabular}{|c|c|c|c|c|c|}
\hline & Albumin & \multicolumn{4}{|c|}{ Globulins } \\
\hline aper electrophoresis & & $\begin{array}{l}\alpha_{1}- \\
3 \cdot 3\end{array}$ & $\begin{array}{l}\alpha_{2}- \\
7 \cdot 2\end{array}$ & $\begin{array}{c}\beta \cdot \\
14 \cdot 4\end{array}$ & $\begin{array}{r}\gamma- \\
12 \cdot 8\end{array}$ \\
\hline Tiselius electrophoresis & .6) $62 \cdot 8$ & $3 \cdot 7$ & $7 \cdot 1$ & $14 \cdot 0$ & $12 \cdot 2$ \\
\hline
\end{tabular}

Full details of the method and the results obtained will be published elsewhere.

$$
\begin{aligned}
& \text { B. LeVIN } \\
& \text { V. G. OBERHolzer }
\end{aligned}
$$

Department of Pathology,

Queen Elizabeth Hospital for Children,

$$
\text { London. }
$$

Jan. 9.

1 Durrum, E. L., J. Amer. Chem. Soc., 72, 2943 (1950).

${ }^{2}$ Cremer, H. D., and 'iselius, A., Biochem. Z., 320, 272 (1950).

${ }^{3}$ Grassman, W., and Hanning, K., Naturwiss., 37, 496 (1950).
Inhibition of Lysine Decarboxylase from E. coli by Homologous Rabbit Antibody

IN studies on the production of antibodies to bacterial amino-acid decarboxylases, we have used lysine decarboxylase from a coliform organism as an antigen. This material was partially purified by a modification of the method of Gale and Epps ${ }^{1}$ in order to reduce its toxicity for animals. The antigen, containing approximately $1.5 \mathrm{mgm}$. protein $/ \mathrm{ml}$., was injected intravenously into rabbits over a period of a month, at the rate of three injections a week. The dosage was gradually increased from $0.2 \mathrm{ml}$. to $1 \mathrm{ml}$. The rabbits were bled ten days after the final injection.

The antiserum was tested for inhibition of the lysine decarboxylase by the manometric method of Miller et al. ${ }^{2}$. Double side-arm Warburg flasks were employed, the antiserum being tipped in after the reaction had proceeded for twenty to thirty minutes. With the homologous enzyme, inhibition of decarboxylase activity was about 90 per cent complete. No inhibition of the corresponding glutamic acid decarboxylase preparations was noted, however, when antiserum to Iysine decarboxylase was added under the same conditions.

When the antiserum and homologous enzyme were mixed and allowed to stand overnight in the refrigerator, a precipitate formed. The residual activity noted above was found only in the precipitate, showing that the enzyme is both precipitated and largely inhibited by the homologous antiserum. This positive finding is in contrast to the results recently reported by Happold and $13 y d^{3} n^{3}$ for tyrosine decarboxylase from Str. foecalis.

A more detailed report of these experiments will be made in a doctoral dissertation to be submitted to Yale University by one of us (A. F. H.). ARTHUR F. HOWE Henry P. Treffers

Department of Microbiology,

Yale University, New Haven, Connecticut. Feb. 21.

${ }^{1}$ Gale, E. F., and Epps, H. M. R., Biochem. J., 38, 232 (1944).

${ }^{2}$ Miller, R. E., Pasternak, Y. Z., and Sevag, M. G., J. Bact., 58, 621 (1949)

${ }^{3}$ Happold, F. C., and Ryden, R., Nature, 168, 115 (1952).

\section{Reported Gamma Glutamyl Activation of Peptide-Bond Synthesis}

IN a recent paper in Nature, Hanes et al. ${ }^{1}$ postulated a $\gamma$-glutamyl transfer mechanism in peptide bond synthesis. It is suggested that the amino-acid forms its first peptide bond with the $\gamma$-carboxyl of glutamic acid by displacing the cysteinyl glycine from glutathione. The amino-acid, now peptide bound, could be further transferred to other peptides. The concept is strengthened in view of the universal and yet unexplained presence of glutathione in all living tissues, the great significance of 'transferring' reactions in biochemistry, and the need for some hypothesis to shed light on the mechanism of protein synthesis. Experiments to test this hypothesis are described in this communication.

Labelled $\gamma$-glutamyl glycine was synthesized using a micro adaptation of the method of LeQuesne and Young ${ }^{2} .40 \mathrm{mgm}$. of doubly labelled glycine $(2 \cdot 5 \mu \mathrm{C} . /$ mgm.) yielded $25 \mathrm{mgm}$. of peptide, the purity of which was verified by elementary analysis (theoretical C, 